\title{
Teacher Opinions on Advantages and Disadvantages of Using Interactive White Board in Primary School
}

\author{
Bilal ERSAN*
}

*Corresponding Author: Bilal ERSAN

\begin{abstract}
It is thought that the use of Interactive White Board (IWB ) generally contributes to the education and training process and is advantageous compared to other boards. However, it is very important for users to decide whether this is right or wrong. In this study, the advantages and disadvantages of IWB use were tried to be determined. Our study is a qualitative research in the pattern of state examination. The working group formed a teacher in different branches ( $f: 43)$ who worked in a primary school in the 2015-2016 school year. Data obtained by open-ended research questions are analyzed by frequency analysis, coding technique and descriptive content analysis. As a result of the analysis, the advantages and disadvantages of using IWB in the view of participants' opinions were determined and solutions were suggested.
\end{abstract}

Keywords: Interactive White Board (IWB), Smart Learning, Instructional Technologies, Information Technologies.

\section{INTRODUCTION}

Developments in Information Technology, technology-based learning is increasingly important. As in all over the world, in Turkey, computer education has been requested to be used in the field and studies related to this are continuing. Computer use studies in education started with the establishment of "computer Education specialization commission in secondary education" in 1984, with Ministry of National Education (MEB) and other institutions in the 1990s (eg. The projects (Basic Education Project , 100\% support to education, computer education support, Intel, etc.) carried out by the World Bank, Ministry of transport and continued with the work towards the establishment of Information Technology classrooms in schools. Support for rapidly developing information technology classes has been gradually reduced towards the end of the 2000s, and the Information Technology classes (e.g.,(Keser and Çetinkaya , 2013).

Ministry of National Education (MEB) and Ministry of Transport started to work on implementation of FATIH (Increasing Opportunities and Technological Improvement Movement) Project, which aims to provide information technology assisted education by providing information technology tools to classrooms in preschool, elementary and secondary levels since November 2010. Within the scope of the FATIH project, for equality of opportunity in education and training and for the improvement of the technology in our schools, for the effective use of the tools of the technologies in the lessons that will be addressed to more senses in the learning-teaching process; board and internet network infrastructure will be provided to all the schools in the pre-school, primary and secondary levels. Every teacher and every student will be given a tablet computer. In order to provide efficient use of Information Technology (IT) equipment established in the classrooms in the learning-teaching process teachers will be given in-service training. In this process, instructional programs will be made compatible with the supporting technologies of Information Technologies and educational e-content will be created (MEB, 2010).

Today, the ways of accessing information through technological developments are also changing and diversifying. This rapid change not only affects every aspect of life but also affects and transforms the education system. Our education system will be able to adapt to changes, meet expectations, and adapt to changing and changing technology. Traditional classroom environments are replaced by new learning environments.. Teaching possibilities, limited to chalk and blackboard, take the place of white boards and IWB (Tarman, 2011). 
In the traditional method, in which the teacher is in the center of the teaching process, alternative functions such as thinking, synthesizing, practicing, using imagination are not used effectively. It is expected that the five sensory organs are used in perception, internalizing the student's knowledge in the modern teaching methods in which the individual learner is taken into consideration, and use what they learn in daily life. Thanks to the IWB, we are trying to solve this problem. IWBs have the potential to transform classes into an interactive learning environment. The goal here is to keep the interest of the student at the highest level in the lessons with versatile stimuli.

When the literature is examined in the literature, it is seen that the opinions of the teachers are frequently applied in evaluating the use of IWB. It is seen that the studies conducted are directed towards teachers' views, attitudes, competences, perceptions, use in different learning environments, educational importance and limitations (Altınçelik, 2009, Beauchamp, 2004, Bulut and Koçoğlu, 2012, Kayaduman, Sırakaya ve Seferoğlu, 2011; Lau, 2011; Türel, 2012; Keser and Çetinkaya, 2013). In general, the results of these studies show that teachers have positive attitudes towards smart boarding and that IWB can contribute to or provide learning to the process. This study is important for the teachers to inform us about the advantages of smart board usage as well as their disadvantages.

\section{METHOD}

In this study, a qualitative research design was used to determine the advantages and disadvantages of IWB use of teachers working in an elementary school. Qualitative research is a research method in which qualitative data gathering methods such as observation, interview and document analysis are used and aimed to present them realistically and holistically in the natural environment of the events (Yıldırım and Şimşek, 2006).

\subsection{Sampling}

The sample of the study consists of 43 teachers in different branches who work in a primary school and actively use the IWB.

\subsection{Collection of Data}

Teachers who participated in the study were informed about the purpose of the study before the data began to be collected. A semi-structured form of open-ended questions was used in the study. Teachers were asked the following two questions to answer regarding interactive whiteboard use: ;

- What are the advantages of using IWB ?

- What are the disadvantages of using IWB ?

\subsection{Analysis of Data}

Frequency analysis, coding technique, descriptive content analysis technique was used in the analysis of the responses of the participants to the open-ended questions. Due to the fact that the study is a qualitative study and the data collection tool is composed of open-ended questions, content analysis and open coding method were used in the evaluation of the obtained data (Yildırım and Şimşek, 2006). The obtained data was transferred to the computer environment and the texts were read several times. Frequency (f) and percentage (\%) values are shown comparatively to determine the frequency of participants' views. Thus, the qualitative data were digitized to increase the reliability of the data, to reduce bias and to provide a comparison between the data. Then the data are coded separately. Similar codes were put together to create themes. The determined themes are interpreted by explaining them in relation to each other. In addition, interpretations were supported by direct quotations from interview texts where deemed necessary.

\subsection{Findings and Comments}

The demographic characteristics of the teachers participating in the survey are as follows.

Table1. Distribution of teachers participating in the survey by gender

\begin{tabular}{|l|l|l|}
\hline \multicolumn{1}{|c|}{ Gender } & \multicolumn{1}{|c|}{ Frequency (f) } & \multicolumn{1}{c|}{ Percentage (\%) } \\
\hline Female & 21 & 48.8 \\
\hline Male & 22 & 51.2 \\
\hline Total & 43 & 100 \\
\hline
\end{tabular}

As seen in Table 1, of the 43 teachers who participated in the research, 21 were female and 22 were male. The proportion of female teachers is $48,8 \%$; while the proportion of male teachers is $51.2 \%$. The distribution of the teachers participating in the research according to the branches is as follows. 
Teacher Opinions on Advantages and Disadvantages of Using Interactive White Board in Primary School

Table2. Distribution of Teachers Participating in Research by Branches

\begin{tabular}{|l|l|l|}
\hline \multicolumn{1}{|c|}{ Branches } & \multicolumn{1}{c|}{ Frequency } & Percent (\%) \\
\hline Turkish & 8 & 18.6 \\
\hline Math & 7 & 16.2 \\
\hline Science & 5 & 11.6 \\
\hline Social studies & 5 & 11.6 \\
\hline English & 4 & 9.3 \\
\hline Religion culture & 4 & 9.3 \\
\hline Visual arts & 4 & 9.3 \\
\hline Music & 3 & 6.9 \\
\hline Traffic safety & 1 & 2.4 \\
\hline Human rights,citizenship and democracy & 1 & 2.4 \\
\hline Game and physical activities & 1 & 2.4 \\
\hline TOTAL & 43 & 100 \\
\hline
\end{tabular}

As can be seen in Table 2, when the branches taught by the teachers participating in the research are examined, it is seen that almost all of the branches that can be used with interactive boards are found in the primary education institutions.

Distribution of the teachers participating in the survey according to service years is as follows.

Table3. Distributions of Teachers Participating in the Survey by Service Year

\begin{tabular}{|l|l|l|}
\hline \multicolumn{1}{|c|}{ Service Year } & \multicolumn{1}{c|}{ Frequency (f) } & \multicolumn{1}{c|}{ Percentage (\%) } \\
\hline$<5$ Years & 5 & 11.6 \\
\hline $5-10$ years & 11 & 25.6 \\
\hline $11-15$ Years & 14 & 32.5 \\
\hline $15-20$ Years & 9 & 21 \\
\hline $20+$ & 4 & 9.3 \\
\hline TOTAL & 43 & 100 \\
\hline
\end{tabular}

As seen in Table 3,88.4\% of the teachers who participated in the research have 5 years and over, $62.8 \%$ have 10 years and more experience.

The distributions of the teachers participating in the research according to years of interactive board use are as follows.

Table4. Distributions of teachers participating in the survey according to years of IWB use

\begin{tabular}{|l|l|l|}
\hline \multicolumn{1}{|c|}{ Interactive White Board Use Year } & Frequency (f) & Percentage (\%) \\
\hline 2 years & 6 & 14 \\
\hline 3 years & 10 & 23.2 \\
\hline 4 year & 12 & 28 \\
\hline 5 years 6 & 6 & 13.9 \\
\hline 6 years 5 & 5 & 11.6 \\
\hline 6 + Years & 4 & 9.3 \\
\hline TOTAL & 43 & 100 \\
\hline
\end{tabular}

As seen in Table 4, $86 \%$ of the teachers who participated in the survey were more than 2 years old; $62.8 \%$ used interactive white boards for more than 3 years.

The answers given to the open-ended questions about the advantages of interactive white board use by the teachers involved in the research are as follows.

Table5. Teachers' Opinions about IWB Advantages

\begin{tabular}{|l|l|l|}
\hline & Frequency (f) & Percentage (\%) \\
\hline Visual Material Use & 22 & 30.1 \\
\hline Fast and Practical & 20 & 27.4 \\
\hline Provides Storage of Information & 15 & 20.6 \\
\hline Provides Storage of Information & 15 & 20.6 \\
\hline Prevent Time Loss & 9 & 12.3 \\
\hline To be clean & 4 & 5.5 \\
\hline Student Contributes & 3 & 4.1 \\
\hline TOTAL & 73 & 100 \\
\hline
\end{tabular}


As shown in Table 5, it has been determined that the teachers' IWB advantages of the survey are:

1. Use of visual material,

2. Fast and practical,

3. Can store information,

4. Prevent time loss,

5. Provide student contribution

English teachers expressed that "language learning visuals" are supported more visually and audibly, that they are supported by visual and auditory aspects, that they prevent distracting attention, they embody the concept, they attract students, they contribute visual memory,

Some teachers said that about the use of visual material, "If a student watches a video about the subject described, or sees a picture, it is easier and quicker to grasp it."

The Science Teacher have emphasized the advantage of using a smart board by saying, "It is important to show pictures and video on behalf of my branch, which is why I think it is advantageous and everything is under your hands."

Some teachers have stated that the use of the IWB is "quick and practical", that they can solve more and faster questions, that the repetition of the subject is easy and practical, that it reduces the amount of mistakes and that pictures and shapes can be drawn more easily and smoothly.

One of the important advantages of IWB is that it allows the teacher to record what he / she has written on the board during the lesson and then use it later when necessary and share it with the students, "

According to the participants IWB "information can be organized, stored in this way easier access to information, teachers book, $\mathrm{CD}$, free from carrying computer. Teachers can reach the data at any time."

The use of the IWB prevents time loss when the course is being processed.

One of the teachers said, "when you are prepared for the lesson, when you have enough documents, we can get a lot of distance in a very short time. Normally we describe a topic with black board in two or three hours, IWB with a course hour can explain."

According to participants, "The IWB is cleaner than the black board. They do not make dust and smell. "

One of the benefits of the IWB is to make a positive contribution to the students. IWB"guides students to multidimensional thinking, enabling the student to open the horizon. Briefly, learning and teaching contribute to the process. "

The opinions of teachers participating in the research on the disadvantages of using the IWB are as follows.

Table6. Teachers' Opinions about Disadvantages of Interactive Boards

\begin{tabular}{|l|l|l|}
\hline & \multicolumn{1}{|c|}{ Frequency (f) } & \multicolumn{1}{c|}{ Percentage (\%) } \\
\hline Technical Issues & $29 \quad 24.8$ \\
\hline Power cut & 28 & 23.9 \\
\hline Waste of time & 18 & 15.4 \\
\hline Student Problems & 17 & 14.5 \\
\hline Virus Transmission & 7 & 6 \\
\hline Teacher Issues & 7 & 6 \\
\hline Problems Due to Wooden Pen & 6 & 5.2 \\
\hline Exposure to Excessive Alert & 5 & 4.2 \\
\hline TOTAL & 117 & 100 \\
\hline
\end{tabular}

As seen in Table 6, it is possible to collect the IWB disadvantages of the teachers who participated in the research in eight main topics,

1. Technical problems, 
2. Power failure,

3. Time loss,

4. Student related problems,

5. Virus infection,

6. Teacher related problems,

7. Problems caused by wooden pencil,

8. Excessive warning exposure,

According to the researchers, the most important problem with the IWB is technical problems with a rate of $24.8 \%$. Technical problems are "problems caused by software errors, program versions, problems caused by the calibration, problems caused by the system, problems caused by the hardware, problems arising from the playing of the boards, students arising from the technology, problems caused by lack of equipment".

Electricity failures are the second most important problem with $23.9 \%$. Electricity interruptions cause the teacher to stop and the teacher to fail. One participant said, "Of course the most important problems are power failures. Especially new teachers are not able to teach in these situations. This includes even 5-6 year old teachers. Even if the generator is switched on, restarting the computer and the board causes a waste of time. "

Time losses are one of the major problems with 15.4\%. "Electrical failures, technical problems, unexpected failures, problems originating from the computer and software" are causing the IWB to shut down. Reopening the IWB is causing a waste of time.

IWB is also affecting students. Students are faced with problems when they use interactive boards, such as "getting used to laziness, not taking notes, reducing writing boot activities, monotonization and pacification".

Another problem with the IWB is viruses. One of the participants said, "The computer can catch a virus. Because it is used by all the students and students of the class who are in that class, it is impossible for the computer to stay clean in parallel with the enormity of the number. The virus I get from that computer is harmful to my personal computer, external drive and USB. "

The IWB can also create problems for teachers. The opinions of the participants in this regard are as follows: "The teacher is restricting the movement area, making it dependent on the screen. The preparatory phase of the course takes a long time. Ready documents acclimate teachers to laziness. In addition, the teachers are far from the blackboard nostalgia. "

The deterioration and the disappearance of the smart pen is also a problem. Students always want to play with smart pen especially small kids in primary school.

Exposure to stimulants such as light, radiation is also an important issue in terms of Health. "My eyes are very uncomfortable because of the light coming from the projection. Another participant said, "brightness is distracting me."

\section{CONCLUSIONS AND RECOMMENDATIONS}

In this study, we aimed to determine the opinions about the advantages and disadvantages of the use of the IWB in the primary education institutions. Participants in different branches and active IWB users are very important in terms of determining the advantages and disadvantages.

We can summarize the advantages of using IWB as follows:

Effective use of visual materials such as pictures, photographs and videos allows the learners to understand the subject better, teaching speed and practicality. The teacher is able to solve more questions by gaining time by reflecting the questions on the board. This prevents loss of time. In addition, course notes and related information can be stored in a computer environment and classified. In this way, the teacher can reach the information he wants at any time. This makes it easier to repeat the subject. IWB also contributes to the student's learning process. It drives students to multi-faceted 
thinking and opens the student's horizons. They are cleaner than other boards. They don't smell dust and smell.

We can summarize the disadvantages of using IWB as follows:

During the use of the IWB, the teachers are experiencing some technical problems arising from software errors, program versions, calibration settings, system, hardware, playing board, lack of technological infrastructure, lack of equipment. Electrical failures are also one of the most important problems. Technical problems and power interruption cause a very serious loss of time, causing the teacher's classroom authority to weaken from time to time. The IWB is able to adapt the student to be lazy, causing habits such as notes, writing, and drawing to diminish. Lessons are monotonous from time to time and the student is passivated in class. Infecting computers with viruses, corruption and disappearance of the board is also a problem. The IWB makes the teacher dependent on the screen, limiting the movement area of the teacher. The preparatory phase of the course takes a long time and the teachers who use the prepared document are accustomed to laziness. In addition, excessive light and radiation threaten the health of teachers and students.

Based on the participants' views on the advantages and disadvantages of interactive boards, the following suggestions can be developed:

- One of the most important problems is to have a generator in schools as a solution to electricity interruptions. Power supply must be used. Battery-interactive boards can be produced.

- In addition to IWB, alternatively blackboards can be found.

- Interactive board software should be developed.

- Instead of pen-written Smart Board, finger-written Touch Boards should be preferred.

- The anti-virus software must be licensed and updated frequently.

- In-service training should be given to teachers in technical matters.

- Interactive board maintenance and software updates must be done on a regular basis.

- There should be technologically competent technical staff in the school who understand the computer and interactive boards.

\section{REFERENCES}

[1] Altınçelik, B. (2009). İlköğretim Düzeyinde Öğrenmede Kalıcıllı̆̆ ve Motivasyonu Sağlaması Yönünden Akıllı Tahtaya İlişkin Öğretmen Görüşleri, Yüksek Lisans Tezi, Sakarya Üniversitesi Sosyal Bilimleri Enstitüsü, Sakarya.

[2] Ateş, M. (2010). Ortaöğretim coğrafya derslerinde etkileşimli tahta kullanımı. Marmara Coğrafya Dergisi, 22, 409-427.

[3] Beauchamp, G. (2004). Teacher use of the interactive whiteboard in primaryschools: Towards an effective transition framework, Technology, Pedagogy and Education, 13(3), 327-348.

[4] Bulut, İ. ve Koçoğlu, E. (2012). Sosyal bilgiler öğretmenlerinin akıllı tahta kullanımına ilişkin görüşleri (Diyarbakır ili örneği). Dicle Üniversitesi Ziya Gökalp Eğitim Fakültesi Dergisi, 19, 242-258.

[5] MEB, (2010). Proje Hakkında, http://fatihprojesi.meb.gov.tr/tr/icerikincele.php?id=6 (son erişim 01.10.2013).

[6] Kayaduman, H.,Sırkaya, M. ve Seferoğlu, S. S. (2011). Eğitimde FATïH projesinin öğretmenlerin yeterlik durumları açısından incelenmesi, XIII. Akademik Bilişim Konferansı (AB11), 2-4 Şubat 2011, İnönü Üniversitesi, Malatya.

[7] Keser, H. ve Çetinkaya, L. (2013). Öğretmen ve Öğrencilerin Etkileşimli Tahta Kullanımına Yönelik Yaşamış Oldukları Sorunlar ve Çözüm Önerileri, Turkish Studies - International Periodical For The Languages, Literature and History of Turkish or Turkic, Volume 8/6 Spring 2013, p. 377-403.

[8] Lau, I. (2011). Teachers for "Smart Classrooms": The Extent of Implementation of an Interactive Whiteboard-based Professional Development Program on ElementaryTeachers' Instructional Practices, InterdisciplinaryJournal Of E-Learning \& Learning Objects, 7, 275-289.

[9] Tarman, B. (2011). Sosyal Bilgiler Eğitiminde Sosyal Bilgiler Laboratuarlarının Yeri ve Önemi, (Ed. R. Turan, A.M. Sünbül\& H. Akdağ), Sosyal Bilgiler Öğretiminde Yeni Yaklaşımlar II, Ankara: Pegem A Yayıncilik. 
[10] Türel, Y. K. (2012). Teachers' negative attitudes towards interactive whiteboard use: Needs and problems, İlköğretim-Online, 11(2), 423.

[11] Yıldırım, A.,Şimşek, H. (2006) Sosyal Bilimlerde Nitel Araştırma Yöntemleri, (8. Basım), Ankara: Seçkin Yayıncilık.

Citation: Bilal ERSAN. "Teacher Opinions on Advantages and Disadvantages of Using Interactive White Board in Primary School "International Journal of Managerial Studies and Research (IJMSR), vol 6, no. 4, 2018, pp. 12-18. doi:http://dx.doi.org/10.20431/2349-0349.0604002.

Copyright: () 2018 Authors. This is an open-access article distributed under the terms of the Creative Commons Attribution License, which permits unrestricted use, distribution, and reproduction in any medium, provided the original author and source are credited. 